\title{
INFORMATION SUPPORT OF MONITORING OF INVESTMENT STRATEGIES IN THE DERIVATIVES MARKET
}

\section{ІНФОРМАЦІЙНИЙ СУПРОВІД МОНІТОРИНГУ ІНВЕСТИЦІЙНИХ СТРАТЕГІЙ НА РИНКУ ДЕРИВАТИВІВ}

\author{
Luchko Galina ${ }^{1}$ \\ Galaiko Nazar ${ }^{2}$
}

DOI: https://doi.org/10.30525/978-9934-571-78-7_11

Abstract. Trends of integration of national, regional, and international markets, globalization of information and communication systems, and development of standards of international law have transformed the world financial market into a unique system, which provides each entity an exceptional opportunity to realize its own economic interests. Domestic financial markets, in general, are open for any transfers, however, lack of regulation of many financial and legal aspects and the presence of currency constraints hamper the dynamic development* of financial markets, in particular, derivatives market which should be an indicator of the state and prospects of changes in both national and world economies. In Ukraine, the derivatives market is in the state of formation. It doesn't perform yet all those functions that the world-class markets of derivative securities fulfil. Derivatives are considered in Ukraine by the majority of market entities as tactical tools for realizing financial goals, therefore, while including them in investment portfolios along with corporate and debt securities, various currencies, market participants have no strategic visions of their use in the long run. As a consequence, they often lose control over the factors affecting the effectiveness of the use of derivatives. The lack of theoretical

\footnotetext{
* In this case, under the development of these markets, we consider an increase in the number of their participants, the volume of executed operations, increase in the level of diversification of financial instruments, etc.
}

${ }^{1}$ Candidate of Economic Sciences,

Assistant Lecturer at Department of Management Technologies,

Lviv Polytechnic National University, Ukraine

${ }^{2}$ Candidate of Economic Sciences,

Senior Lecturer at Department of Finance, Banking and Insurance,

State Higher Educational Institution "Banking University", Ukraine 


\section{Chapter «Economic sciences»}

background and applied tools for the formation of information support of construction and implementation of investment strategies in the derivatives market is the cause of difficulty of efficient use of derivatives.

\section{1. Ветуп}

Передумовою результативності моніторингу реалізації інвестиційних стратегій на ринку деривативів є належний інформаційний супровід суб'єктів моніторингу. Процес формування інформаційного супроводу суб'єктів моніторингу передбачає підготовчий і предметний етапи. Перший з них включає: формування класифікації інформації у залежності від потреб суб'єктів ринку деривативів; встановлення відповідності видів інформації джерелам їі отримання; ідентифікування характеристик інформаційних технологій, які необхідні для отримання, обробки і використання інформації; визначення взаємозв'язків між ініціаторами і виконавцями інвестиційних стратегій для налагодження комунікаційних каналів обміну даними; обумовлення вимог до рівня освіти користувачів інформаційними технологіями і правил їх безпечного використання. Елементами другого є: застосування організаційних заходів із підвищення освіти користувачів інформаційними технологіями, проведення семінарів, курсів тощо; придбання або створення власними силами інформаційних технологій, налагодження їх дії, монтування мереж тощо.

Проведене дослідження дозволило обгрунтувати критерії результативності інформаційного супроводу суб'єктів моніторингу. Аргументовано, що до них належать: повнота охоплення суб'єктів деривативів засобами автоматизації, відповідність інформації та інформаційних технологій потребам суб'єктів, рівень економічної результативності інформаційного супроводу. Відповідність інформаційного супроводу вказаним критеріям сприятиме результативності аналізування та оцінювання інвестиційних стратегій на ринку деривативів, а також обгрунтованості інвестиційних рішень.

Щодо показників, які характеризують ефективність реалізації інвестиційних стратегій, то доведено, що моніторинг зміни їхніх значень необхідно здійснювати у розрізі показників результативності формування і використання, а також диверсифікованості інвестиційних ресурсів. Обчислення розробленого комплексу показників, а також визначення їх коефіцієнтів вагомості уможливлює отримання суб'єк- 
тами ринку деривативів полівекторної характеристики ефективності реалізації обраної інвестиційної стратегії.

\section{2. Інформаційний супровід моніторингу інвестиційних стратегій на ринку деривативів}

Формування інвестиційних стратегій на ринку деривативів вимагає моніторингу відповідності його параметрів діючим умовам ринкового середовища. Більшість фахівців 3 питань формування систем моніторингу стверджують, що їхня результативність залежить від: рівня диверсифікованості видів, форм і методів контролю; розвиненості інформаційного супроводу; здатності осіб, які здійснюють моніторинг, застосовувати креативні підходи до покращання системи моніторингу у процесі іï експлуатації [1; 3-5; 7-17]. Більашість операцій із деривативами суб'єкти ринку деривативів здійснюють за допомогою спеціального програмного супроводу або використовуючи послуги професійних організацій. Діяльність останніх залежить від здатності аналізувати та оцінювати зміни положень національних, зарубіжних і міжнародних правових актів щодо здійснення операцій із деривативами, розвиненості інформаційної інфраструктури і можливостей використовувати інформаційно-комунікаційні ресурси, зокрема щодо попиту і пропозиції на організованому ринку торгівлі деривативами, зміни курсової вартості активів, що лежать в основі деривативів, факту укладання угод про розширення обсягів діяльності емітентів, рішень емітентів щодо згортання певних видів діяльності тощо. Створення ефективної системи моніторингу є формування такої системи інформаційного супроводу інвестиційних стратегій, яка б характеризувалась високим рівнем автоматизації управління, відповідністю інформації та інформаційних технологій потребам користувачів, а також економічною результативністю. На рис. 1 наведено графічну модель моніторингу як функції інформаційного супроводу реалізації інвестиційних стратегій на ринку деривативів.

Як бачимо з вищенаведеної моделі функція моніторингу виконується усіма суб'єктами ринку деривативів на основі використовуваного ними інформаційного супроводу, яке включає бази даних і технології отримання, зберігання, оброблення і використання інформації. Використовуючи власті та існуючі у зовнішньому середовищі комунікаційні мережі суб'єкти ринку деривативів здійснюють моніторинг ринку і ринкового 


\section{Chapter «Economic sciences»}

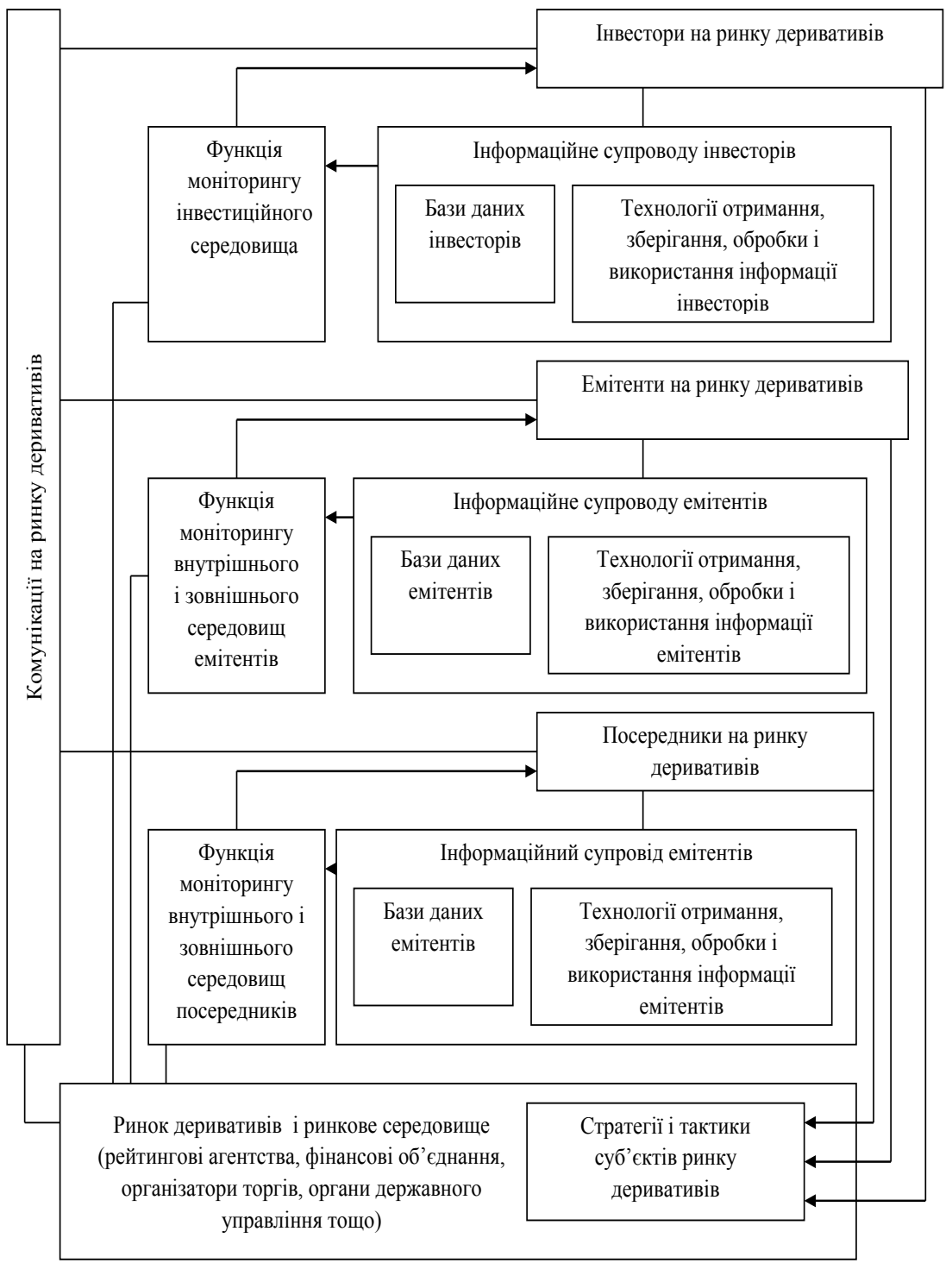

\section{Рис. 1. Моніторинг як функція інформаційного супроводу реалізації інвестиційних стратегій на ринку деривативів}




\section{Luchko Galina, Galaiko Nazar}

середовища, а також стан реалізації сформованих ними стратегій і тактик. На рис. 2 наведено процесійну модель моніторингу інвестиційних стратегій на ринку деривативів. Перший етап вимагає формування високоінформативної для фінансових аналітиків системи моніторингу. Виконання цього завдання передбачає структуризацію інформації у залежності від потреб користувачів, а саме за джерелами отримання - внутрішня і зовнішня; за часом надходження і використання - ретроспективна, поточна і перспективна; за актуальністю - актуальна, неактуальна; за формою фіксування - документальна, не документальна; за станом оброблення - необроблена, у стадії оброблення, оброблена; за формою подання - усна, письмова; за рівнем доступності інформації - конфіденційна, з обмеженим доступом, загальнодоступна; за видами діяльності підприємства - фінансова, кадрова, маркетингова тощо.

Інформація може одночасно характеризуватись різними класифікаційними ознаками. 3 огляду на це, для супроводу прикладного значення класифікації інформації іiі слід групувати на засадах декомпозиції. Логічно побудована класифікація інформації може використовуватись за основу для ідентифікування іiї значущості при формуванні і ухваленні стратегічних інвестиційних рішень щодо побудови і реалізації інвестиційних стратегій на ринку деривативів.

У табл. 1 наведено запропоновану класифікацію інформації. Актуальною слід вважати інформацію, яку керівники фінансових організацій можуть використати для ухвалення рішень щодо вибору, заміни або регулювання ходу реалізації раніше обраної інвестиційної стратегії на ринку деривативів. Актуальною може бути як ретроспективна, так i поточна і перспективна інформація, тому ці види інформації виділяти недоцільно. Серед загального масиву отримуваної суб'єктами ринку деривативів інформації найактуальнішими є відомості, які підтвердились у результаті використання різних джерел і методів їх залучення.

Інформація може бути актуальною також, якщо вона не характеризується об'єктивністю, наприклад, коли відомості надійшли з одного джерела, шляхом застосування одного з методів отримання інформації, проте така інформація вимагає обробки і перевірки перед тим, ніж використовуватись за основу для ухвалення інвестиційних рішень на ринку деривативів. Таким чином, неактуальною $є$ інформація, яка у результаті додаткової перевірки та обробки даних, що надійшли 3 одного джерела не підтвердились або виявились несуттєвими. 


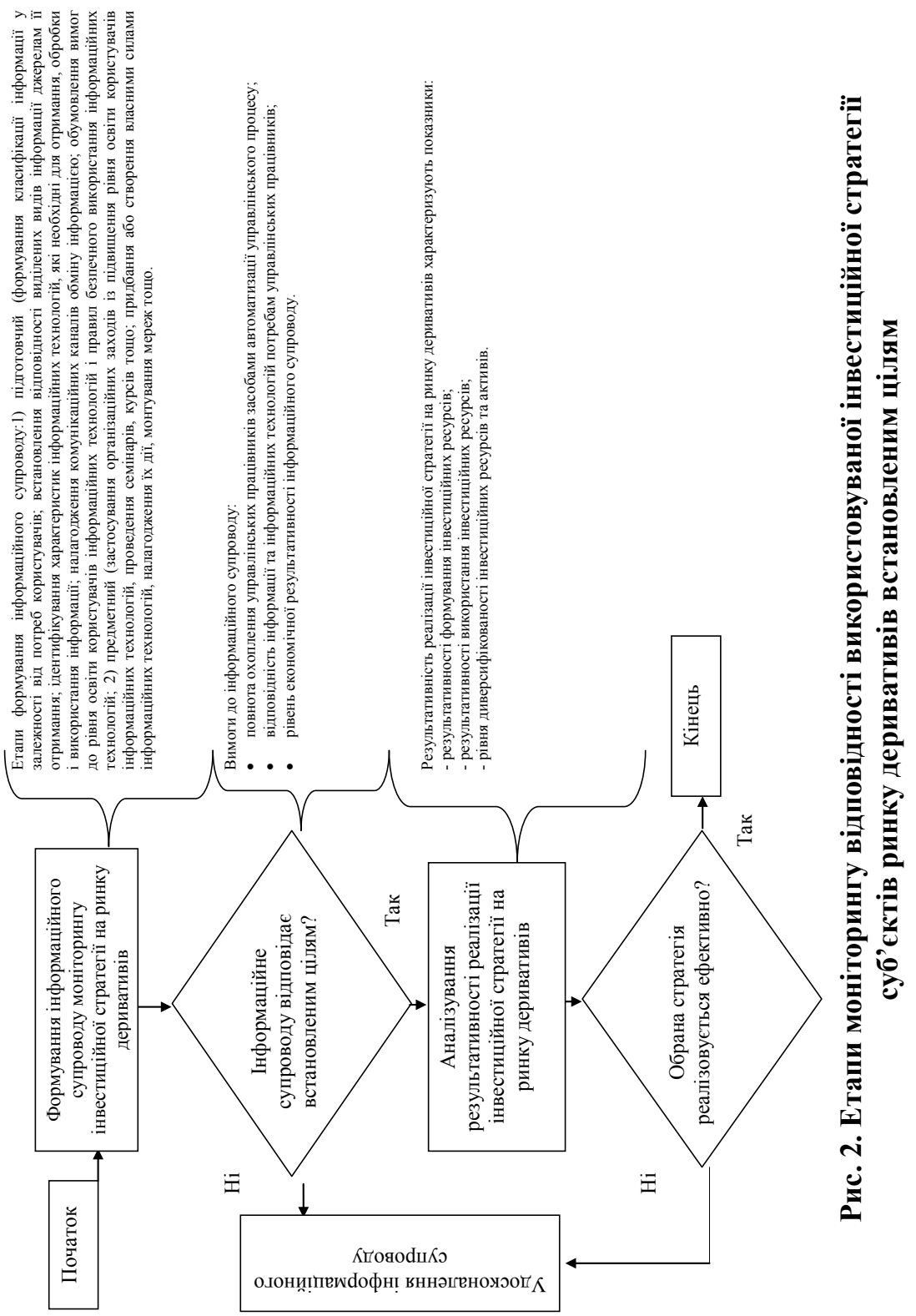




\begin{tabular}{|c|c|}
\hline \multicolumn{2}{|c|}{$\begin{array}{c}\text { Пропонована класифікація інформації, } \\
\text { адаптована до баз даних суб'сктів ринку деривативів }\end{array}$} \\
\hline Класифікаційні ознаки & Види інформації \\
\hline \multicolumn{2}{|c|}{ Конкретні (аналітичні) ознаки і види інформації } \\
\hline За методом отримання & $\begin{array}{l}\text { • інформація, отримана шляхом перевірки } \\
\text { документації; } \\
\text { • інформація, отримана шляхом проведення усних } \\
\text { опитувань; } \\
\text { • інформація, отримана шляхом здійснення запитів; } \\
\text { • інформація, отримана шляхом спостереження; } \\
\text { - інформація, отримана шляхом тестування } \\
\text { працівників; } \\
\text { • інформація, отримана шляхом ознайомлення із } \\
\text { судженнями фахівців, аналітиків, службовців бірж, } \\
\text { органів державної влади тощо. }\end{array}$ \\
\hline За джерелом отримання & $\begin{array}{l}\text { • інформація, отримана від фінансових аналітиків; } \\
\text { • інформація, отримана від представників державних } \\
\text { органів управління і представників правоохоронних } \\
\text { органів; } \\
\text { • інформація, отримана від керівників і фахівців } \\
\text { міжнародних організацій і багатонаціональних } \\
\text { компаній; } \\
\text { • інформація, отримана від конкурентів; } \\
\text { • інформація, отримана від емітентів основних і } \\
\text { деривативів, якими володіє компанія; } \\
\text { • інформація, отримана від організаторів торгів } \\
\text { деривативами і активів, що лежать в їх основі; } \\
\text { • інформація, отримана із засобів масової інформації } \\
\text { тощо. }\end{array}$ \\
\hline $\begin{array}{l}\text { За готовністю } \\
\text { до підготовки } \\
\text { управлінських рішень }\end{array}$ & $\begin{array}{l}\text { • інформація, яка потребує перевірки і додаткової } \\
\text { обробки; } \\
\text { • інформація, готова до підготовки управлінських } \\
\text { рішень. }\end{array}$ \\
\hline \multicolumn{2}{|r|}{ Загальна ознака і види інформації } \\
\hline За об’єктивністю & $\begin{array}{l}\text { • об’єктивна інформація; } \\
\text { • необ’єктивна інформація. }\end{array}$ \\
\hline \multicolumn{2}{|r|}{ Результативна ознака і види інформації } \\
\hline За актуальністю & $\begin{array}{l}\text { • актуальна інформація; } \\
\text { • неактуальна інформація. }\end{array}$ \\
\hline
\end{tabular}




\section{Chapter «Economic sciences»}

В умовах активізування процесів інформатизації суспільства більшість підприємців потребують застосування сучасних інформаційних технологій. До інформаційних технологій належать програмні продукти, комп'ютерна техніка, засоби зв'язку, комунікаційні канали, які в цілому є сукупністю способів отримання, оброблення, зберігання і використання інформації. Інформаційні технології класифікують за [18]:

- за способом використання засобів обчислювальної техніки під час обробки даних - інформаційні технології у централізованих автоматизованих інформаційних системах; інформаційні технології у децентралізованих системах обробки даних;

- за способом реалізації в автоматизованих інформаційних системах - традиційні, нові, високі; ступенем охоплення завдань управління - інформаційні технології електронного оброблення даних; інформаційні технології автоматизації функцій управління; інформаційні технології підтримки прийняття рішень; інформаційні технології електронного офісу; інформаційні технології експертної підтримки;

- за типом користувацького інтерфейсу - пакетні; діалогові; мережеві; способом побудови мережі - локальні; багаторівневі; розподілені;

- за моделями обчислювального процесу - хост-орієнтовані інформаційні технології; інформаційні технології, що реалізують модель процесу 3 розподіленими ресурсами; інформаційні технології «клієнт-сервер»;

- за видом інформації, що обробляється - системами управління базами даних, алгоритмічні мови, табличні процесори; текстові процесори; графічні процесори; експертні системи; мультимедіа;

за проектними системами, що обслуговуються - інформаційні технології бухгалтерського обліку; інформаційні технології банківської діяльності; інформаційні технології податкової діяльності; інформаційні технології страхової діяльності тощо.

Під час формування інформаційного супроводу моніторингу інвестиційних стратегій на ринку деривативів важливим завданням проектантів системи інформаційного супроводу є ідентифікувати вимоги до інформаційних технологій. Ці вимоги значною мірою визначаються: необхідністю доступу користувачів інформації до певних джерел інформації; характером оброблення інформації, іiї обсягом, швидкістю отримання, оброблення і передавання даних; складністю побудови баз даних, кількістю користувачів базами; вимогами до супроводу конфіденційності інформаційних ресурсів. 


\section{Luchko Galina, Galaiko Nazar}

Результатом виконання усіх видів робіт на підготовчому етапі формування інформаційного супроводу є створення моделі (проекту) інформаційного супроводу. Завданням предметного етапу є реалізувати розроблений проект на практиці і здійснити навчання користувачів інформацією та інформаційними технологіями.

Наступним етапом моніторингу відповідності використовуваної інвестиційної стратегії $є$ оцінювання відповідності сформованого інформаційного супроводу встановленим параметрам, а саме:

- повноті охоплення розробників і реалізаторів інвестиційних стратегій засобами автоматизації управлінського процесу (найбільш чисельними структурними підрозділами суб'єктів ринку деривативів протягом 2006-2010 рр. були відділи матеріально-технічного супроводу і відділи кадрів. На другому місці за чисельністю були відділи маркетингу та безпеки. Своєю чергою, на третьому - бухгалтерії та фінансові відділи. У процесі дослідження виявлено, що не всі підрозділи досліджуваних суб'єктів ринку деривативів, які найбільш чисельні є найбільш забезпеченими комп'ютерними технологіями. Аналіз показав, що найбільша кількість комп'ютерів у 2006 р. припадала на бухгалтерії компаній, відділи маркетингу і безпеки. У 2010 р. ситуація суттєво не змінилась, проте з 2008 р. до найбільш комп'ютерно забезпечених почали належати також відділи матеріально-технічного постачання. Кількість персональних комп'ютерів, що припадала на одного працівника у бухгалтеріях аналізованих компаній у 2018 р. порівняно із 2014 р. зросла із 0,67 до 0,82, у фінансових відділах знизилась із 0,30 до 0,29, у відділах кадрів зросла із 0,11 до 0,18 , у відділах маркетингу зросла із 0,52 до 0,69 , у відділах матеріально-технічного супроводу збільшилась із 0,14 до 0,28, у відділах безпеки знизилась із 0,37 до 0,34 у інших структурних підрозділах підприємства зросла із 0,28 до 0,39 [6]);

- відповідності інформації та інформаційних технологій потребам суб'єктів ринку деривативів (експерти у галузі формування та сервісного обслуговування інформаційних систем стверджують, що рішення про створення і результативність використання інформаційних систем та технологій слід ухвалювати на засадах врахування безпечності їх використання, відповідності їх параметрів професійним потребам користувачів, здатності взаємодіяти із зовнішніми мережами);

- рівню економічної результативності інформаційного супроводу (інформаційне супроводу суб'єктів ринку деривативів в період активі- 
зування процесів інформатизації вимагає постійного збільшення обсягів витрат на: комп'ютеризацію виробничо-господарських процесів, підвищення рівня освіти працівників, сервісне обслуговування засобів автоматизації. 3 огляду на це, виникає небезпека зростання обсягу умовно-постійних витрат у структурі витрат суб' єктів ринку деривативів, які фактично прямо не впливають на обсяг валового доходу, проте мають безпосередній вплив на частку витрат компаній у структурі валового доходу. Це вимагає вибору такої стратегії формування інформаційного супроводу, щоб витрати на інформаційне супроводу сприяли покращенню значень показників економічного розвитку, а не навпаки).

\section{3. Оцінювання рівня інформаційного супроводу моніторингу інвестиційних стратегій на ринку деривативів}

За результатами проведених досліджень нами розроблено метод оцінювання рівня інформаційного супроводу моніторингу інвестиційних стратегій на ринку деривативів. Його сутність полягає у розрахунку показників, які характеризують рівень інформаційного супроводу, визначенні коефіцієнтів їх вагомості та визначенні взаємозв'язків між ними:

1. Оцінювання повноти охоплення управлінських працівників суб'єктів ринку деривативів засобами автоматизації управлінського процесу

$$
P_{o}=\frac{K_{a}}{K_{z}},
$$

де $P_{o}$ - коефіцієнт повноти охоплення управлінських працівників засобами автоматизації управлінського процесу, частки одиниці; $K_{a}-$ чисельність управлінських працівників, залучених до формування $\mathrm{i}$ реалізації інвестиційної стратегії на ринку деривативів, робочі місця яких автоматизовано, чол.; $K_{z}$ - загальна чисельність управлінських працівників, залучених до формування і реалізації інвестиційної стратегії на ринку деривативів, чол.;

Економіко-управлінський зміст цього коефіцієнта полягає у ідентифікації рівня автоматизації процесу вироблення інвестиційних рішень у межах інвестиційної стратегії на засадах використання деривативів. Аналізування матеріалів суб'єктів ринку деривативів показало, що оф-лайнові умови отримання та обробки фінансової інформації, як правило, не виправдовують себе, оскільки кон'юнктура фінансових 
ринків, зокрема, організованих ринків часто змінюється погодинно. Це вимагає якомога вищого рівня автоматизації робочих місць управлінських працівників, створення умов для он-лайнової роботи із фінансовою інформацією, а також із відповідними контрагентами.

2. Оцінювання відповідності інформації та інформаційних технологій потребам управлінських працівників.

2.1. Оцінювання відповідності інформації потребам управлінських працівників

$$
O=\frac{M_{f}}{M_{z}} \cdot k_{1}+\frac{D_{f}}{D_{z}} \cdot k_{2},
$$

де $O$ - коефіцієнт об'єктивності інформації, отриманої управлінськими працівниками для формування і реалізації інвестиційної стратегії на ринку деривативів, частки одиниці; $M_{f}$ - кількість методів, використаних управлінськими працівниками для отримання інформації; $M_{z}$ - загальна кількість методів, які могли бути використаними управлінськими працівниками для отримання інформації; $D_{f}$ - кількість джерел, використаних управлінськими працівниками для отримання інформації; $D_{z}$ - загальна кількість джерел, з яких могла бути отримана управлінськими працівниками інформація; $K_{1}, K_{2}$ - коефіцієнти вагомості показників, які характеризують об'єктивність інформації, отриманої управлінськими працівниками.

Економіко-управлінський зміст цього коефіцієнта базується на такому постулаті: чим вищим є рівень поінформованості суб'єктів управління про чинники, які впливають на об'єкт управління, тим ймовірнішим $є$ те, що суб'єкти управління приймуть раціональне управлінське рішення. Поінформованість суб' єктів управління лінійно залежить від кількості альтернативних джерел і методів отримання інформації. 3 огляду на це, чим вищим $є$ значення цього коефіцієнта, тим нижчою є ймовірність суб'єктивізму рішень, пов'язаних із реалізацією інвестиційної стратегії на ринку деривативів.

Вищевказаний коефіцієнт може набувати значення від 0 до 1.

2.2. Оцінювання відповідності потребам використовуваних управлінськими працівниками інформаційних технологій:

$$
T=\frac{T_{f}}{T_{n}},
$$

де $T$ - коефіцієнт відповідності потребам використовуваних управлінськими працівниками інформаційних технологій, частки одиниці; 


\section{Chapter «Economic sciences»}

$T_{f}$ - кількість інформаційних технологій, які фактично використовують управлінські працівники при формуванні і реалізації інвестиційної стратегії на ринку деривативів, шт.; $T_{n}$ - кількість інформаційних технологій, які необхідні управлінським працівникам для ефективного, на їх думку, формування і реалізації інвестиційної стратегії на ринку деривативів, шт.

Економіко-управлінський зміст цього коефіцієнта полягає у тому, що суб'єкти управління, які уповноважені приймати інвестиційні рішення, повинні мати якомога вищі можливості щодо застосування інформаційних технологій, необхідних для акумулювання, обробки, зберігання і передавання інформації. В даному випадку йдеться як про ручні, так і автоматизовані інформаційні технології. Щоправда проведені дослідження вказують на те, що чим більшою є частка автоматизованих інформаційних технологій, тим вищим $є$ рівень продуктивності праці управлінських працівників і меншою є ймовірність технічних помилок при аналізі даних, суб'єктивізму у виборі критеріїв прийнятності варіанту управлінського рішення тощо.

У такий спосіб, оцінювання відповідності інформації та інформаційних технологій потребам управлінських працівників слід здійснювати за формулою

$$
V=O \cdot K_{3}+T \cdot K_{4}
$$

де $K_{3}, K_{4}$ - коефіцієнти вагомості показників, які характеризують відповідність інформації та інформаційних технологій потребам управлінських працівників.

3. Оцінювання рівня економічної результативності інформаційного супроводу. Оцінювання результативності інформаційних систем та інформаційного супроводу суб'єктів ринку деривативів здебільшого здійснюють шляхом використання доходного, затратного або ринкового підходів [2]. 3 огляду на те, що у більшості компаній не прослідковується лінійних зв'язків між обсягом отримуваного прибутку і витратами на формування і використання інформаційного супроводу, то доходний підхід не доцільно використовувати для оцінювання результативності інформаційного супроводу. Те саме стосується і ринкового підходу. Оскільки ринок інформаційних технологій розвивається дуже динамічно, то ринкова вартість використовуваної суб'єктом ринку деривативів комп'ютерної техніки і відповідного програмного супро- 
воду, як правило, є нижча за їх балансову вартість. Проте ця різниця викликана не тим, що використовувані інформаційні технології не відповідають потребам користувачів, а тим, що собівартість надання послуг-новинок, які з'являються на ринку, все більше і більше знижується. 3 огляду на це, найдоцільнішим є застосовувати витратний підхід для оцінювання результативності рівня інформаційного супроводу. Його сутність полягає у виявленні рівня витрат на формування та підтримку належного рівня інформаційного супроводу організації у порівнянні з компаніями-конкурентами

$$
W=\frac{W_{B}-W_{A}}{W_{B}},
$$

де $W$ - коефіцієнт економічної результативності інформаційного супроводу, використовуваного для моніторингу інвестиційних стратегій на ринку деривативів; $W_{A}$ - витрати на формування та підтримку належного рівня інформаційного супроводу досліджуваної організації; $W_{B}$ - витрати на формування та підтримку належного рівня інформаційного супроводу аналогічної організації.

Оскільки витрати підприємства, які не пов'язані із збільшенням обсягу валового доходу (умовно-постійні витрати), лінійно не пов'язані із отриманням конкретних економічних вигод, а є вимушеними, оскільки виникають у зв'язку із необхідністю утримання адміністративного персоналу суб'єкта ринку деривативів, то очевидно, що їх зростання, у більшості випадків, розцінюється аналітиками як негативне явище. При пошуку резервів підвищення прибутку ця група витрат часто розглядається як перспективний напрям отримання економії. Враховуючи це, економіко-управлінський зміст вищенаведеного коефіцієнта полягає у тому, що чим меншими є витрати на формування та підтримку належного рівня інформаційного супроводу суб'єктів ринку деривативів, у порівнянні із конкурентами, тим більшими є перспективи збільшення прибутку. Щоправда це твердження має зміст тільки тоді, коли інші 3 вищенаведених коефіцієнтів мають високі значення. Значення цього коефіцієнта має бути більшим або дорівнювати нулю.

Таким чином, рівень інформаційного супроводу суб'єктів, які здійснюють моніторинг інвестиційних стратегій на ринку деривативів характеризує множина індивідуальних коефіцієнтів

$$
\cup R=P_{o} \cup V \cup W,
$$


де $U R$ - множина показників, що характеризують рівень інформаційного супроводу суб'єктів, які здійснюють моніторинг інвестиційних стратегій на ринку деривативів.

Наступними етапами моніторингу є аналізування та оцінювання результативності обраної інвестиційної стратегії на ринку деривативів. Як вже зазначалось, результативність реалізації інвестиційної стратегії характеризують рівень результативності формування і використання інвестиційних ресурсів, в тому числі деривативів, а також рівень диверсифікованості інвестиційних ресурсів та активів (табл. 2).

Вищевказані показники слід оцінювати, виходячи з умов

$$
\begin{aligned}
& O_{z}-O_{b} \neq 0 ; \frac{O_{z}-O_{b}}{O_{b}} \succ 0 ; \quad V_{z}-V_{b} \neq 0 ; \frac{V_{z}-V_{b}}{V_{b}} \prec 0 ; \\
& \frac{P_{d_{z}}}{V_{d_{z}}} \succ \frac{P_{d_{b}}}{V_{d_{b}}} \text { або } R_{x} \succ 0 . ; \\
& K_{d z}-K_{d b} \neq 0 ; \frac{K_{d z}-K_{d b}}{K_{d b}} \succ 0 ; K_{a z}-K_{a b} \neq 0 ; \quad \frac{K_{a z}-K_{a b}}{K_{a b}} \succ 0 .
\end{aligned}
$$

Економіко-управлінський зміст наведеної вище множини показників полягає в полівекторній характеристиці інвестиційної стратегії на ринку деривативів. Оцінювання результативності реалізації цієї стратегії має бути полівекторним, оскільки суб'єкти управління, які відповідальні за ії формування і реалізацію, мають різні інформаційні потреби та різні доступні на конкретний момент часу резерви підвищення результативності реалізації стратегії. Так, хоча показник результативності використання інвестиційних ресурсів актуальний на усіх етапах реалізації стратегії, його значення не дає інформації про динаміку витрат на формування активів. Відсутність моніторингу за цими даними може негативно позначитись на фінансовій стійкості суб'єкта ринку деривативів і збалансованості грошових потоків. Ця інформація $€$ важливою в ті періоди реалізації стратегії, коли зростає дебіторська заборгованість і можуть виникнути труднощі із погашенням отриманих кредитів. У зв'язку з цим, результативність реалізації інвестиційної стратегії необхідно оцінювати та аналізувати за допомогою показника результативності формування інвестиційних ресурсів, який вказує на приріст обсягу і вартості інвестиційних ресурсів у звітному періоді у порівнянні з базовим, а також показника диверсифікованості 


\section{Таблиця 2}

\section{Показники, які характеризують результативність реалізації інвестиційної стратегії на ринку деривативів}

\begin{tabular}{|c|c|}
\hline Назви показників & Способи розрахунку показників \\
\hline $\begin{array}{l}\text { Показник } \\
\text { результативності } \\
\text { формування } \\
\text { інвестиційних } \\
\text { ресурсів }\left(R_{o v}\right)\end{array}$ & $\begin{array}{l}\qquad R_{o v}=\left(\frac{O_{z}-O_{b}}{O_{b}} \cdot k_{5}+\frac{V_{z}-V_{b}}{V_{b}} \cdot k_{6}\right) \cdot 100 \% \text {, } \\
\text { де } O_{z}-\text { обсяг інвестиційних ресурсів у звітному періоді, тис. } \\
\text { грн.; } O_{b}-\text { обсяг інвестиційних ресурсів у базовому періоді, } \\
\text { тис. грн.; } V_{z}-\text { вартість інвестиційних ресурсів }{ }^{2} \text { у звітному } \\
\text { періоді, \%; } V_{b}-\text { вартість інвестиційних ресурсів у базовому } \\
\text { періоді, \%; } k_{5} \text { - коефіцієнт вагомості приросту обсягу } \\
\text { інвестиційних ресурсів у звітному періоді у порівняні з } \\
\text { базовим, частки одиниці; } k_{6}-\text { коефіцієнт вагомості приросту } \\
\text { вартості інвестиційних ресурсів у звітному періоді у } \\
\text { порівняні з базовим, частки одиниці. }\end{array}$ \\
\hline $\begin{array}{l}\text { Показник } \\
\text { результативності } \\
\text { використання } \\
\text { iнвестиційних } \\
\text { ресурсів }\left(R_{x}\right)\end{array}$ & $\begin{array}{l}\qquad R_{x}=\left(\frac{P_{d_{z}}}{V_{d_{z}}}-\frac{P_{d_{b}}}{V_{d_{b}}}\right) \cdot 100 \% \text {, } \\
\text { де } P_{d_{z}}-\text { прибуток, отриманий у звітному періоді від реалізації } \\
\text { операцій з деривативами, тис. грн.; } V_{d_{z}}-\text { балансова вартість } \\
\text { деривативів }{ }^{3} \text { на дату формування балансової звітності, } \\
\text { тис. грн.; } P_{d_{b}}-\text { прибуток, отриманий у базовому періоді від } \\
\text { реалізації операцій з деривативами, тис. грн.; } V_{d_{b}}-\text { балансова } \\
\text { вартість деривативів у базовому періоді, тис. грн. }\end{array}$ \\
\hline $\begin{array}{l}\text { Показник } \\
\text { диверсифікованості } \\
\text { інвестиційних } \\
\text { ресурсів }\left(D_{r a}\right)\end{array}$ & $\begin{array}{l}\qquad D_{r a}=\left(\frac{K_{d z}-K_{d b}}{K_{d b}} \cdot k_{7}+\frac{K_{a z}-K_{a b}}{K_{a b}} \cdot k_{8}\right) \cdot 100 \%, \\
\text { де } K_{d z}-\text { кількість джерел інвестиційних ресурсів у звітному } \\
\text { періоді; } K_{d b}-\text { кількість джерел інвестиційних ресурсів у } \\
\text { базовому періоді; } K_{a z}-\text { кількість об'єктів інвестиційної } \\
\text { діяльності у звітному періоді; } K_{a b}-\text { кількість об'єктів } \\
\text { інвестиційної діяльності у базовому періоді; } k_{7}-\text { коефіцієнт } \\
\text { вагомості приросту кількості джерел формування } \\
\text { інвестиційних ресурсів у звітному періоді у порівняні з } \\
\text { базовим, частки одиниці; } k_{8}-\text { коефіцієнт вагомості приросту } \\
\text { кількості об'єктів інвестиційної діяльності у звітному періоді } \\
\text { у порівняні з базовим, частки одиниці. }\end{array}$ \\
\hline $\begin{array}{l}\text { Множина показників, } \\
\text { які характеризують } \\
\text { результативність } \\
\text { реалізації інвестицій- } \\
\text { ної стратегії на ринку } \\
\text { деривативів }\left(\bigcup E_{s}\right)\end{array}$ & $\cup E_{s}=R_{o v} \cup R_{x} \cup D_{r a}$ \\
\hline
\end{tabular}

2 У даному випадку під вартістю інвестиційних ресурсів розуміємо витрати, пов'язані з їхнім залученням. Якщо йдеться про кредитні ресурси, то це сплачені відсотки за кредит, а якщо про власні кошти, то витрати на здійснення додаткової емісії акцій чи облігацій.

3 Балансова вартість деривативів - це вартість деривативів, за якою вони відображені у балансі підприємства. 


\section{Chapter «Economic sciences»}

інвестиційних ресурсів, який інформує суб'єктів управління про приріст кількості джерел інвестиційних ресурсів, а також приріст об'єктів інвестиційної діяльності у звітному періоді у порівнянні із базовим.

\section{4. Висновки}

Побудова і реалізація інвестиційних стратегій на ринку деривативів відбувається за результатами постійного моніторингу інвестиційного середовища, кон'юнктури ринку деривативів, змін у правових актах тощо. Доведено, що забезпечення результативності моніторингу стану реалізації інвестиційних стратегій на ринку дериватів вимагає параметризації і формалізації складових елементів об'єкта моніторингу. Виділені етапи формування і реалізації інвестиційних стратегій, а також побудована технологія моніторингу їхнього виконання дозволять суб'єктам ринку деривативів реалізовувати стратегічні інвестиційні цілі за садах їхнього узгодження з ринковою місією суб'єктів і використанням кон'юнктурних можливостей у формі реалізації поточних інвестиційних операцій.

\section{Список літератури:}

1. Бланк И.А. Управление финансовыми ресурсами. Москва : «Омега-Л», $2011.768 \mathrm{c}$.

2. Есипов В., Маховикова Г., Теренова В. Оценка бизнеса. СПб.: Питер, 2001. $416 \mathrm{c}$.

3. Мішина С. Організаційно-економічний механізм управління фінансовими ресурсами на підприємстві. Харків: ХНЕУ, 2006. 110 с.

4. Мних С.В., Барабаш Н.С. Фінансовий аналіз. Київ: КНТЕУ, 2014. $536 \mathrm{c}$.

5. Ковалев В.В. Финансовый менеджмент: теория и практика. Москва: Проспект, 2006. 1016 с.

6. Контролювання та регулювання економічного розвитку підприємства: проблеми, методологічні та прикладні аспекти: монографія / О.Є. Кузьмін, С.В. Князь, Н.О. Шпак, В.А. Новицький. Львів: Видавництво Національного університету «Львівська політехніка», 2006. 148 с.

7. Опарін В. Фінансові ресурси: проблеми визначення та розміщення. Вісник Національного банку України. 2000. № 5. С. 10-11.

8. Brealey R.A., Myers S.C. Principles of corporate finance. New York: McGraw-Hill, 2011. 976 p.

9. Brigham E.F., Houston J.F. Fundamentals of financial management. Mason: Cengage Learning, 2009. 752 p.

10. Друкер П. Эпоха разрыва. Ориентиры для нашего меняющегося общества. Москва: Вильямс, 2007. 336 с. 


\section{Luchko Galina, Galaiko Nazar}

11. Балабанов И.Т. Основы финансового менеджмента. Как управлять капиталом. Москва: Финансы и статистика, 1994. 382 с.

12. Поддєрьогін А.М., Білик М.Д., Буряк Л.Д. Фінанси підприємств. Київ: КHEУ, 2004. 546 c.

13. Бернстайн П. Фундаментальные идеи финансового мира. Эволюция. Москва: Альпина, Бизнес Букс, 2009. 247 с.

14. Martelli A. Scenario building and scenario planning : state of the art and prospects of evolution. Futures Research Quarterly. 2001. Summer. Pp. 57-70.

15. Mintzberg H., Quinn J. The strategy process. Revises European Edition. Sumantra Gh,1996.

16. Кравченко О.О. Сценарне фінансове планування і прогнозування на залізничному транспорті: теорія і практика. Київ: ДЕТУТ, 2013. 300 с.

17. Ringland G. Scenarios in business. Chichester: John\&Sons Ltd, 2002. 288 p.

18. Пономаренко Є.В. Формування стратегії розвитку інформаційних ресурсів підприємства: автореф. дис. на здобуття наук. ступеня канд. екон. наук: спец. 08.06.01 «Економіка, організація і управління підприємствами» / Є.В. Пономаренко. Луганськ, 2006. С. 19.

\section{References:}

1. Blank, I.A. (2011). Upravleniye finansovymi resursami [Management of financial resources]. Omega-L, Moscow, Russia.

2. Yesipov V., Makhovikova G., Terenova V. Otsenka biznesa. SPb.: Piter, 2001. 416 s.

3. Mishina, S. (2006). Orhanizatsiyno-ekonomichnyy mekhanizm upravlinnya finansovymy resursamy na pidpryyemstvi [Organizational-economic mechanism of management of financial resources at the enterprise]. KhNEU Publ., Kharkiv, Ukraine.

4. Mnykh, Ye.V., Barabash, N.S. (2014). Finansovyy analiz [Financial analysis]. KNTEU Publ., Kyiv, Ukraine.

5. Kovalev, V.V. (2006). Finansovyy menedzhment [Financial management: theory and practice]. Prospect, Moscow, Russia.

6. Kuz'min O.Ye. (2006). Kontrolyuvannya ta rehulyuvannya ekonomichnoho rozvytku pidpryyemstva: problemy, metodolohichni ta prykladni aspekty [monohrafiya], L'viv, Vydavnytstvo Natsional'noho universytetu «L'vivs'ka politekhnika».

7. Oparin, B. (2000). Financial resources: problems of detection and deployment. Bulletin of the National Bank of Ukraine, vol. 5, pp. 10-11.

8. Brealey, R.A. and Myers, S.C. (2011). Principles of corporate finance, McGraw-Hill, New York, USA.

9. Brigham, E.F. and Houston, J.F. Fundamentals of financial management, Cengage Learning, Mason, USA.

10. Drucker, P. (2007). Epokha razryva. Oriyentiry dlya nashego menyayushchegosya obshchestva [The era of the gap. Landmarks for our changing society], Williams Publ., Moscow, Russia.

11. Balabanov, I.T. (1994). Osnovy finansovogo menedzhmenta. Kak upravlyat' kapitalom [Fundamentals of financial management. How to manage capital]. Finansy i statistika, Moscow, Russia. 
12. Poddyer'ohin, A.M., Bilyk, M.D. and Buryak, L.D. (2004). Finansy pidpryyemstv [Finance of the enterprises], KNEU Publ., Kyiv, Ukraine.

13. Bernstayn, P. (2009). Fundamental'nyye idei finansovogo mira. Evolyutsiya [Fundamental ideas of the financial world. Evolution]. Al'pina, Biznes Buks, Moscow, Russia.

14. Martelli, A. (2001). «Scenario building and scenario planning: state of the art and prospects of evolution», Futures Research Quarterly, Summer, pp. 57-70.

15. Mintzberg H. (1996). Quinn j. The strategy process.Revises European Edition. Sumantra Gh, pp. 81-101.

16. Kravchenko, O.O. (2013). Stsenarne finansove planuvannya i prohnozuvannya na zaliznychnomu transporti: teoriya i praktyka [Scenario financial planning and forecasting in rail transport: theory and practice]. DETUT Publ., Kyiv, Ukraine.

17. Ringland, G. (2002). Scenarios in business, John\&Sons Ltd, Chichester, UK.

18. Ponomarenko, Ye.V. (2006). Formuvannya stratehiyi rozvytku informatsiynykh resursiv pidpryyemstva [avtoref. dys. na zdobuttya nauk. stupenya kand. ekon. nauk: spets. 08.06.01 "Ekonomika, orhanizatsiya i upravlinnya pidpryyemstvamy"]. Luhansk. 